\title{
Hugh MacLennan As I Knew Him
}

\section{by Louise Gareau-Des Bois}

This is the text of the Hugh MacLennan Memorial Lecture, under the auspices of the Friends of the Libraries, McGill University, 13 October, 1993.

In her paper, Louise Gareau-Des Bois recalls her friendship with Hugh MacLennan and the letters they exchanged throughout the years, mostly during his stay in Grenoble from Ocotber 1963 to the following April.

His translator begins by describing her enthusiasm when, as a young girl, she first read Two Solitudes, and her initial disbelief when she learned that the book, already translated in six languages, still lacked a French version. She then procedes to tell us about her first meeting with the author, and the thousand and one episodes which marked the making of her translation. The latter was published in Paris, at les Editions Spes, in December 1963, eighteen years after the intial publication of the book. It was only in 1978 that Louise Gareau-Des Bois' translation was eventually published here, by les Editions H.M.H., in Montreal. A paper-back edition came out two years ago.

Voici le texte de la conférence MacLennan du 13 octobre 1993, que parraine chaque année les amis des bibliothèques de l'Université McGill.

Dans son exposé, Louise Gareau-Des Bois relate sa longue amitié avec Hugh MacLennan et la correspondance qu'elle échangea avec lui au cours des années, spécifiquement lors du séjour qu'il effectua à Grenoble d'octobre 1963 à avril de l'année suivante.

Sa traductrice décrit d'abord son enthousiasme quand, jeune fille, elle lut Two Solitudes pour la première fois, et son incrédulité quand elle apprit que déjà traduit en six langues, le livre n'avait point encore de version française. Elle nous raconte ensuite sa première rencontre avec l'auteur, et les mille et une aventures qui marquèrent l'histoire de sa traduction. Celle-ci parut enfin à Paris, aux Éditions Spes, en décembre 1963, dis-huit ans après la parution originale. Ce n'est qu'en 1978 que Deux Solitudes fut reprise au Québec par les Éditions H.M.H., à Montréal, qui publièrent aussi une édition de poche il y a deux ans.

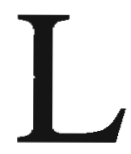
et's go back in time. It is early April 1958. A young girl goes to the library and comes back with a book. It's Hugh MacLennan's Two Solitudes. She has heard about it and from the outset, is very curious. As she first opens it, she recognizes the name of her favorite author, Rilke, and the thought chosen by MacLennan as an epigraph. She closes her eyes, the novel still in her hands, and the wonderful words fill her once again with joy and hope: "L'amour, c'est deux solitudes qui se protègent, que s'éprouvent et s'accueillent l'une l'autre". The words come to her mind in French, because it is in her mother tongue that she first read Rilke. She then goes back to Two Solitudes and reads aloud the epigraph, but in English this time: "Love consists in this, that two solitudes protect, and touch, and greet each other". And right at this moment, she decides that the author who chose such a beautiful leitmotiv for a book of his must be a wonderful human being, and she becomes even more eager, if possible. Such was the disposition of mind in which the young girl--myself some thirtyfive years ago--began reading Two Solitudes.

My life--as I suppose indeed most lives---has been marked by a series of interesting and at times, even rather strange coincidences. The very same week, a short article regarding MacLennan's novel appeared in Le Devoir: it stated that despite having been translated in Holland, Sweden, Spain, Czechoslovakia, Germany and Japan, Two Solitudes was still looking for a French 
translator. "Look no more", I said inwardly but resolutely. "Here I am!"

Being a Taurus, it did not occur to me for a moment that I might be refused. I did not reflect on my inexperience as a literary translator but instead was comforted by the fact that I had just been granted a degree in translation from the Université de Montréal. Recently, I had won two first prizes in poetry and a play was a finalist at the first competition sponsored by the Théâtre du Nouveau-Monde. I was doomed to become a writer, I knew this in my flesh and bones, and still did not know whether to lament or rejoice at the fact. Confronted by Two Solitudes, I was not rebuffed by its 618 pages. It needed a French translation, I would do it. I was just about to be engaged, but even that would not come in the way! I was going to do it.

A quick look in the telephone directory was fruitless, but I finally managed to locate MacLennan's address on Summerhill Avenue. I then set about to write him, requesting his authorization to translate Two Solitudes. My letter, dated April 21st, was, as you may guess, very enthusiastic and, I must admit, quite naive.

MacLennan wrote back two days later, on my birthday. Needless to say that I was quick to see a sign of the gods in this! I would now like to read his first letter to me.

1535 Summerhill Avenue April 23, 1958

\section{Dear Miss Gareau:}

I hope that you will be able to read this. An attack of bursitis in my left arm makes it impossible for me to use the typewriter at the moment.

Thank you for your kind words about my books. Two Solitudes now lies so far behind me that it seems that another person wrote it. It is more than thirteen years since it was first published. This year the New York firm Dusll, Sloan \& Pearce, who published it originally, have issued a new cloth-cover edition. In Canada, at least, the book will probably live for a while.
Now about the French translation. Two Solitudes has been translated into Dutch, Spanish, Swedish, Czech, German and Japanese. But there is no French translation.

The reason is that I signed a contract in 1945 with Lucien Pariseau et Cie. Pariseau kept the rights for three years and then failed. By that time it seemed too late for a French translation.

Six years ago a young Canadian of Ottawa, André d'..., began a new translation. He may have finished it. So far as I know, he is now in Paris, but I have several times tried to find him and have failed.

I do know, however, that it is not easy to persuade a French firm to publish a book which is (or will be) fifteen years old by the time it reaches the French market. Even if you undertook the task, you would be unable to make any money out of it proportionate to the time and talent you expended on it. Also, my London agent has long ago given up trying to interest a Paris publisher in Two Solitudes.

A Montreal publisher in the French language would be the only possible solution here. If you could find one, he would be able to tell you 1) whether he wished to publish; 2) what he would pay you as a translator.

Finally, there is the problem of Mr. d'. I suppose I could trace him if I tried hard enough. But before I could authorize another French translation, I would have to find him.

I'm sorry this is so confused, but I'm most grateful for your letter and for your interest and kind words.

Sincerely, Hugh MacLennan

Coincidence again: having both been raised in a then fenceless Town of Mount Royal, I knew by sight the "Monsieur d'." to whom MacLennan had referred. Moreoever, standing the day before in a Number 4 bus, I had caught a glimpse of the handsome young man at 
Hugh MacLennan as I Knew Him

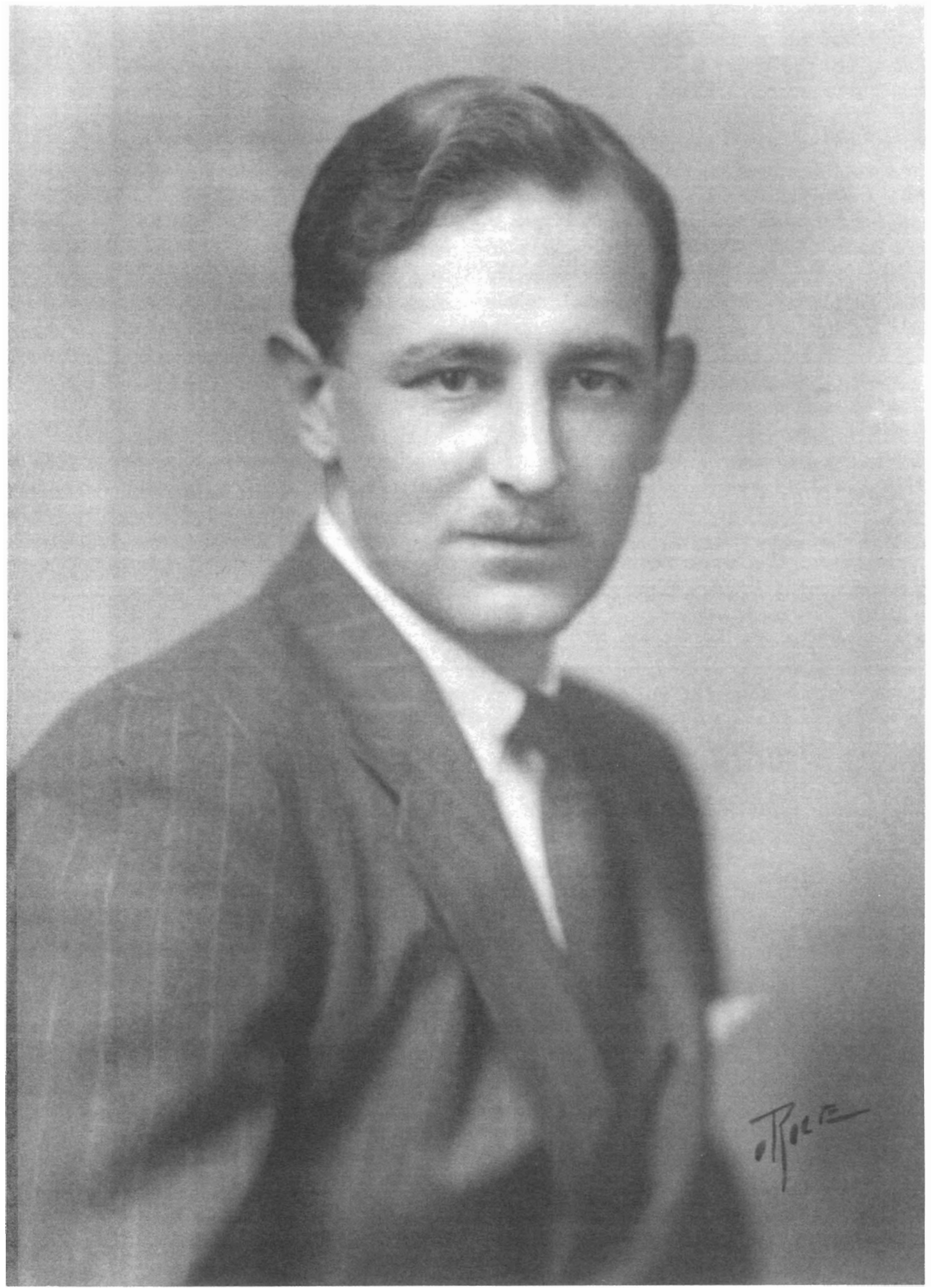

Hugh MacLennan by Rice of Montreal, 1932. 


\section{Hugh MacLennan as I Knew Him}

the corner of Guy and Sherbrooke Streets! Not only was I quick to inform MacLennan of this new development, but obligingly, I went as far as providing address and phone number! The wait could now begin.

It was not long--though it seemed like ages--before MacLennan rang to inform me that he had now been successful in reaching Monsieur d'. The latter, it turned out, had had better things to do in Paris than to translate a book! He was therefore renouncing all rights to the French translation, and I was being summoned that very morning to MacLennan's apartment.

I was to be there promptly at 11.30 . He was curious, he had said over the phone, to meet the young girl who was rash enough to want to translate the 618 pages of his Two Solitudes. I was to bring him the excerpts--two or three chapters--that I had already translated.

I remember it very vividly--it was a lovely Spring day, bright and sunny. Contrary to my usual tardiness in those days, I was there promptly on time, and at 11.30 sharp, rang the bell at 1535 Summerhill Avenue. A middle-aged man, tall and smiling, welcomed me in. Dressed in tweeds and smoking his then eternal pipe, he seemed to be appraising me in a sort of shy if discreet way: would this young girl of twenty or so be able to accomplish such a task? Nothing seemed less certain, or so I imagine he must have thought at that moment. Who could blame him?

Trying to dissipate our mutual feeling of awkwardness (it was not done, in those days, to visit a gentleman at home!) I ventured to blurt out that I liked the decor. The room was all at once elegant and cosy. It exuded great charm--not unlike my host at the time-and was filled with books and objets d'art. One felt happy being there. By contrast, I sensed vaguely that the inhabitant of this lovely decor was not himself a happy man: I was soon to learn that Dorothy Duncan, his first wife, had died just some months before.

He seemed touched by my spontaneity and asked to see the excerpts of my translation. The moment of truth had come, there was no going back. Both Taurus determination and Guardian Angel had abandoned me to my fate, there I was, alone and frightened, waiting for the verdict!
MacLennan was to write some time later, specifically in an essay published in 1960 entitled French is a Must for Canadians, that (and I quote) "my inability to speak it is a constant shame to me, and I recognize it as the severest educational handicap in my entire life". (End of quote). Thus spoke the Rhodes scholar of the not-so-far away Oxford years.

He was able, on the other hand, not only to grasp the meaning of the language, but also to appreciate style and rhythm. Soon, he was telling me how pleasantly surprised he was with my translation: the rhythm of my sentences was a perfect match for his, was he saying now. I remember to this day uttering a long, eloquent sigh of relief: I had passed the test!

My happiness, however, was short-lived: MacLennan was going on to say that it was up to me to find a publisher. Horror! Granted, he had mentioned that in his first letter to me, but I had tried to forget the tiresome "detail"! A succession of ominous, closed doors and of stern and ventripotent publishers passed gloomily in my mind, and I came close to abandoning the whole project. Had I fully realized at the time what would become of my life for the next five years, I would probably have done so. Instead, I smiled and agreed to start making the round. I was not going to be disappointed.

The doors kept closed and publishers--in whatever shape they came--remained adamant: they were NOT going to rely on a young writer--and a girl at that--for such an important and enormous task! Thank you, Mademoiselle.

However, one of them relented and agreed to read my translation. I was to do about half the book--some three hundred pages--and await the verdict. Such was the lot of a literary translator in those days.

Then came the day we returned from our honeymoon, in May 1959. The rough seas we had faced on our way back from Europe had seemed more merciful that the stern letter which was now trembling in my hands: it stated that my use of the subjunctive having been found to be somewhat careless, it had been decreed that the job was indeed, AS EXPECTED, beyond my powers. Thank you again, Mademoiselle-pardon, Madame! 


\section{Hugh MacLennan as I Knew Him}

After a few months of playing house and generally adjusting to married life, came a day when my husband, feeling no doubt a certain restlessness in his young bride, suggested gently that perhaps I should consider returning to the grindstone: "You have worked so much already, said he, unfortunately echoing the voice of my conscience, that it would be a shame to abandon and to have done all of this for nothing".

I could only agree, however reluctantly: I had been saying this to myself for the past few months, and now my husband was reading my mind! What was I to do but to resume the work and become once again a "woman of paper", "une femme de papier" as I used to refer to myself in those days.

You may think that all of this is taking up too much of my allotted time, but one must consider that it is mostly through Two Solitudes that I have known Hugh MacLennan. On the other hand, it is also a rather rare instance when a translation comes out eighteen years after publication date, thus the need, I feel, for a rather lengthy presentation. But take heart! I am soon coming to the correspondence we exchanged during his stay in Grenoble, from October 1963 to the following April.

However, we are not quite there as yet. Indeed, it is only December 10, 1960, and MacLennan, with whom I got in touch again recently, sends me a formal letter of agreement which I am to sign and forward back to him. A few weeks before, I have, at his suggestion, met a French publisher, the formidable Mademoiselle Dumat, of les Editions Spes, in Paris, who was indeed most pleased with the first part of my translation and who has agreed to publish it if (I quote) "the quality of the second half is as good as the first". Thus MacLennan's letter to me which said in part:

"I hereby grant you the exclusive right to offer your translation to publishers in French for a period of one year from the date of this letter, it being understood that the first publisher to consider the translation will be Editions Spes, 79 rue de Gentilly, Paris.

It is understood that if your translation of Two Solitudes has not been accepted within a year from the date of this letter, or by December 10 ,
1961, all claims on me are null and void, and you will retire the translation.

When you have affixed your signature below, this letter will constitute an agreement between us.

Sincerely yours,

Hugh MacLennan

Once again, there was no time to be lost. I set to work at a feverish pace, les Editions Spes having been even more demanding than the author and having insisted on a July 31st, 1961, deadline. I shall spare you the gory details but will only admit to an 18 hour work-day during the last three weeks. My mother would bring in meals and my brother Jean, who was already at that time a busy young architect, typed innumerable pages to help me out. As for my husband, he was as usual kind, supportive and patient, and frankly, I'm not sure that the reverse was always true!

It is strange how details connected to an important event in one's life remain untouched by time: I still remember the kind and jovial postal employee in Dorval to whom I spoke on the phone on "deadline day" who promised to keep the bag open for me until late in the afternoon. When I finally got there, exhausted but so very relieved, there he was, seemingly as happy as I was. The next day, on August 1st, my husband and I left for Prince Edward Island, the sun and the sea, and ten months later, our first child, Valérie, was born. The "woman of paper", at long last, was shedding her cocoon.

My dear friend Hugh (who was always very decorous and who will only start addressing me by my first name many years later), my dear friend Hugh was very happy at the prospect of my translation being published in France. However, my own happiness once more turned to anxiety as the December 10, 1961 dealine for publisher's approval crept closer and closer; still, there was no word from the formidable but unfortunately ailing Mademoiselle Dumat. MacLennan, on the other hand, was getting more and more impatient with her and her publishing firm: I was getting more and more anxious. Finally two days before the deadline, on December 8th, came her answer: she agreed to publish my translation as long as I would 


\section{Hugh MacLennan as I Knew Him}

work some more on the introduction, the quality of which, according to her, being unequal to that of the remainder of the translation. What relief! If that was her only condition!...

Finally, on March 30th, 1962, nearly four years after my first communication with Hugh MacLennan, I received my contract with the exciting promise of an account of one thousand and two hundred francs. In those days, it represented about $\$ 258$. The account or "à valoir", as it was called, was never followed by anything else. MacLennan called my translation a "labour of love". It was never meant to be anything else.

I will only add at this time that my manuscript remained on the shelves of les Editions Spes for more than two years. Was it their own devious way to impose on their writers the virtue suggested by their name? Who knows. Let us simply say for the record that after a lengthy and voluminous correspondence with the author, his agent in New York, Miss Gregory and mostly Mademoiselle Dumat, who wanted to expurgate my manuscript of all possible canadianisms but who, I'm happy to report, finally lost the battle, Deux Solitudes came out at long last in Paris in December 1963. Some fifteen years later, les Editions Hurtubise HMH published my translation here, in Montreal, and a new paperback edition came out recently.

\section{$* * * * * * *$}

We are now coming to the gist of my correspondence with Hugh MacLennan. Some months before, he had addressed me the following letter in which he refers to a forthcoming seminar which some of you might have attended:

\section{North Hatley \\ June 16, 1963}

\section{Dear Madame Gareau-Desbois:}

Many thanks for the copies of your letters to Blanche Gregory and Mile Dumat. I can't understand why the latter is so slow, but this seems always the way with Paris publishers. Certainly you should have the proofs in July if they intend to publish in early October.
Our title seems to have passed into the currency of the Canadian language, at least at the present. McGill Graduate Alumni Association is holding a panel seminar next October called Two Solitudes with Laurendeau, Faribault, Frank Scott, Howard Ross and myself in the chair, each man to speak his own language.

After a very bad time, the political situation in Canada seems to me to be improving. I wish I could say the same for the economic situation. I do not agree with some that economics is all there is to a nation, but l'm afraid it's much more important and certainly more difficult and intractible, than some of the ardent intellectuals among the University of Montreal students seem to believe. However, I suppose we'll get through somehow.

With all good wishes.

$$
\begin{aligned}
& \text { Sincerely, } \\
& \text { Hugh MacLennan }
\end{aligned}
$$

In October of the same year, Chatelaine published excerpts of my translation, and on that occasion MacLennan sent me a most enlightening letter with regard to both Two Solitudes and the political situation of Quebec at that time.

\section{Montreal}

October 8, 1963

\section{Dear Madame Gareau-Desbois:}

Three copies of Chatelaine have just reached me, and I hope you are pleased with the production they gave of your translation. I still don't know when Spes publishes the book in its entirety, but I suppose it will be this fall. I had been curious to know what sections Chatelaine would choose, and was rather suprised (at first) by the ones they did select. They certainly avoided the controversial elements in the novel, and probably they were right. For these could not be fairly produced in brief excerpts. Anyway, I hope the book as a whole is well received in Quebec, and for my part I am deeply thankful that a French Canadian translated it. 
You have had a hard and, I would guess, at times a heart-breaking task, and I hope it has not been one you regret.

In a little over a fortnight my wife and I leave Canada for seven months in Europe, and hope to spend most of that time in France. Perhaps I will at last succeed in mastering the French language, but the real purpose is to get free for a time, to obtain a new perspective and to write a new novel. Only time will tell whether I can or not.

People tell me that Two Solitudes is as true as it was twenty years ago--meaning by this that the situation is the same. I don't believe this. I believe rather that the general public, both French and English, has finally accepted the main outlines of the picture in the novel. But the public mind is always a generation behind actual developments within a society.

What is going on in Quebec today seems to me to have many overtones of the Russia of the late 19th century, though there are of course innumerable differences. I am desperately sorry for those boys in the FLQ, though organized society would have invited suicide if it had tried to prevent the law from taking its course. Here was a situation that was almost pure Dostoyevsky. Only a handful of those boys could ever have had any dealings with Les Anglais, yet they acted with a passion equal to that of young Irishmen at the time the English army was occupying their country. During the riot at la Place des Arts, the young people were shouting: "à bas les bourgeois!" So out of this, for the time being, will probably come a volte face on the part of the Quebec establishment towards les Anglais, as a counterbalance against the true revolutionary ferment within the younger elements of French Canadian society.

I write this because my intuition tells me that the basic situation has changed almost out of recognition. On October $18 \mathrm{I}$ am to be chairman of a panel discussion before the McGill Alumni Association (he repeats here the gist of his previous letter to me, but then goes on by adding): I predict that $95 \%$ of the questions will be addressed to Faribault and Pelletier. Yet I have the feeling that all of us will be talking in the past tense, much as Les Etats Generaux were talking in the past tense in Paris in 1789

All good wishes,

Sincerely, Hugh MacLennan

Shortly thereafter, MacLennan left for Europe with Frances, his second wife, and thus began one of the happiest periods of his life and also of mine. We corresponded steadily during that time, and for the very young woman that I was then, the experience was all at once enriching and stimulating. Do let me read his first letter of that period.

Hôtel de Savoie
avenue d'Alsace-Lorraine
Grenoble, Isère, France
7th of January 1964

Dear Madame Gareau-Desbois:

We have been in Grenoble now for nearly seven weeks and have seen the sun only on one day: A most beautiful country when visible, and as I bought a small Peugeot with a contrat de rachat we have at least been able to drive a little, though the roads are dangerous for small cars on account of verglas. (Strange that he does not mention French drivers! I continue with the letter:) But for all that, it has been a wonderful experience. I was too much involved at home, have not really been away for any length of time since I wrote Two Solitudes, and at this particular moment, one learns more about Canada from living in France than from any place I could imagine. We deliberately kept out of Paris because we wanted to know France, and it is amusing to see once again the plain evidence of human incapacity to see the obvious. As you of course know, the strength of France is in the provinces and the French provincial is the most private, staunch invididual who ever lived. These folk in the Dauphiné remind me of Lowland Scots--their women dress, if possible, more dowdily, their houses are so cold that any normal 


\section{Hugh MacLennan as I Knew Him}

Canadian would die of pneumonia in them, and the better I come to know them, the more I love them. But make no doubt of this: there is more vitality in French Canada than there is here, more youth, gaiety and exuberance, and--saddest of all-the famous French cuisine has all but collapsed since the war. Partially this may be caused by a plain lack of a variety of foods, especially meats, which are in great demand since the population has increased so dramatically. But I do wish that more of my Francophone compatriots would stay in places like Grenoble, Valence, Chalons, Rennes and Tours than in Paris. Prices are so terrifying that I wonder seriously how people live, and can only guess that they do so by stinting themselves of good, solid food and heat, and the kind of clothes most Montrealers take for granted. The best index I can think of here is the cost of horsemeat in the the shops--from $\$ 1.35$ to $\$ 1.55$ a pound. (And he goes on with a joke in French): En Québec on trouve des gens qui parlent 'joual' mais personne qui le mange!

I learned from home that copies of your translation had appeared, so I wrote Mademoiselle Dumat and asked her to send me three here. I have just finished reading it, and appreciate more than ever what a truly enormous task you had in translating that novel into French. Perhaps it is impossible for any author to grasp a translation of his work, though I read here practically nothing but French, but to me your translation has such vigour that it seems like a new book.

And this brings me to something else:

My increasing impression in France is that the long rule of l'Académie française is literally emasculating the language. I know this sounds like heresy in French ears but, to quote your line from Capt. Yardley, "j'vous signe mon papier que c'est sacrement vrai!" They have become such purists that the sheer use of the French language has become an end in itself. God knows Quebec needs to do something along these same lines --- so many people at home chew their words so badly it is next to impossible for an Anglophone to understand them -- I find the
French here exquisite and easy to hear -- but it is Alexandrine and decadent to make the use of a language an end in itself, and to say, as often they do, "ce mot n'existe pas" because the professors have decided that it should not. That is why, I am certain, there is such lack of vitality in most contemporary French fiction -- why the earthy quality has gone out of it and they write like tired people. Too polite? I wonder. But though they can smile, they have forgotten how to laugh.

Therefore, I will be fascinated by what result, if any, your translation is going to have here. They are going to laugh at some of the dialogue, but the English did exactly the same thing twentyfive years ago when they encountered the best American writers. And look at the situation now! The English discovered a vitality in American speech they lacked in their own. Your translation, I would guess, has a Rabelesian quality long missing in French literature, and it certainly has the speech of the farm people at that time.

Mademoiselle Dumat wishes me to go to Paris for the lancement which she says she is arranging with the Canadian embassy. I will go if I can and tell you about it if it happens. At the moment, I don't think we have an ambassador, but I gather from a Montreal paper that Lionel Chevrier is going to be appointed to Paris. I have met him several times but don't really know him.

Once again, fortunately or unfortunately, Deux Solitudes is timely. What fools people are, repeating from one generation to the next the same pattern. But I do think, néanmoins, that things are really better at home. Quebec blew off too far in one direction, now we'll have to wait a while until Ontario blows off in reverse, and then we'll go ahead. I was all in favour of Quebec blowing off up to the FLQ, but last Spring I felt that Lesage and Lévesque were waiting too long to say where they stood. I still think they waited a little too long. For any way you look at it, separatism is impossible economically. If French did not have such a damnably difficult grammar, 


\section{Hugh MacLennan as I Knew Him}

I think bilingualism would come about in necessary areas, but it is useless to pretend that it is not a very difficult language for an Anglophone to master. I even go to Berlitz, and they all say this is the case. Still, much can, should and will be done. Living here, I often think that Canada - I mean English Canada as well -- resembles France more than any other country on this side of the water. The French here are provincials, and in many ways .. though their manners are better -- the Dauphinois are still at bottom more like Scotch Canadians than like French Canadians. Every Frenchman, of course, who lives elsewhere tells a foreigner he has made a mistake unless be lives where that particular Frenchman lives himself. In Grenoble, they think I'm particularly intelligent to have understood, even in Canada, that Grenoble is the heart of France. On visite Paris mais on n'y habite pas. (this in French, of course).

\section{All good wishes, Hugh MacLennan}

The very next day, Hugh wrote me the most moving letter of all those he addressed to me. I shall read it in its entirety, because it reveals the generous and very vulnerable man he was.

\section{Hotel de Savoie Grenoble, France January 8, 1964}

Dear Madame Gareau-Desbois,

Last night, sitting in bed, I was so moved that I wrote you a letter in French about your translation. This morning, with a heavy day of writing ahead of me, I re-read it, realized that nobody could possibly read my handwriting, and that probably I had some mistakes in syntax, so this will go in English.

I finished reading your translation from end to end, and it was a poignant experience. I don't think I have read the whole of Two Solitudes since I read the galley proofs, nor any part of it since I read the first half of your original translation.
This was like reading a book by somebody entirely different. The translation was utterly faithful, yet again and again the French language made it seem new to me. I found myself asking myself, with a certain incredulity, how it had been possible for a man in his thirties, a Nova Scotian, at that time unable to speak a single French sentence, to have written this particular book. It gives me a very strange sensation, and a certain curious confidence in the universal authority of the artistic intuition. Also, the thing seems just as true now as it ever was.

What moved me literally to tears was the meeting of Tallard and McQueen and his walk to the Cathedral. You have done this, I think, marvellously, and here, I truly believe the French language -- perhaps because Tallard himself is so French, perhaps because something in your own experience made you feel intensely about it -business men are so universal, aren't they -- here, certainly, I think your translation has more power than the original.

I have worked at such a frantic pace all my life, almost never pausing to consider any significance in my past work, that the book was almost a shock to me. Am I still the man who wrote it? What is the continuing identity with any of us? Suddenly I realized that Athanase Tallard, whom a younger, a much younger Hugh MacLennan dragged out of somewhere more than twenty years ago, is very close to my own present age, and I feel his tragedy more intensely, through your translation, than I did when I wrote it.

Also, of course, I am now in France, and I am sure that the scene of Tallard recalling what it meant to him, as a French Canadian, to be in France, is absolutely authentic. The book seems to me now more than a French Canadian novel, but more essentially one than it appeared when I wrote it. In your translation it is now essentially a FRENCH novel.

You told me that you wrote it as a labour of love. It is quite clear to me that you did just that, for there is a freshness in your translation I can 
truly feel. I have read practically nothing but French since coming here, and can read at the rate of about 150 pages in my scant spare time during the day. Perhaps now I can feel a little better for French style than in the past, though of course I cannot be sure of this.

But there is immense vigour in your writing, far more than in the writing of contemporary Frenchmen on this side of the water, more than may be comfortable for them. I hope they will be kind to our book, and I confess I felt (and was surprised to feel it) a curious pride to see the imprint PARIS on a book of mine -- or was it because, in this particular case, Two Solitudes was conceived and begun in 1941, and was finished just before the D-Day landings in Normandy, at a time when few people could be sure there would be any literature ever again emerging from Paris or any part of France?

Anyway, and this is all I can say now and perhaps it is wrong -- when I put your translation down I had several quite different ideas concerning it, as follows:

1. This, which was once an English book, is now also a French one.

2. The dialogue of the villagers, vigorous though it is, may perhaps, in Quebec, assist GerinLajoie and Lesage in their educational reform, for you have reproduced it perfectly and VISUALLY, and without intending to do it, you have also made a point as regards bilingualismm which no French Canadian, to the best of my knowledge, has ever appreciated. It is this: The Anglophone in Quebec is up against an impossible situation as regards learning French for two reasons: if he speaks to an educated person, the educated person speaks such excellent English that he cannot practice his conversation without mutual embarrassment. If he speaks to a French Canadian who has no English, he cannot possibly follow what he says because he chews his words and mixes up the grammar, precisely as Frère Untel said. I go to Berlitz for help in my pronunciation, and my very intelligent teacher, who speaks an exquisite
French, said this to me: "DON'T try to speak so fast. Learning French is like learning to ski. Un Anglais speaks from the throat, we speak from the lips. It is possible to speak French very fast only IF you have mastered a lip control, just as it is possible to ski fast only when you have mastered every necessary movement in the control of your skis. Failing that, you chew your words, you actually misrepresent their proper sounds"

Of course, educated French Canadians do NOT chew their words, but so very many do. And the Anglo-Canadian who mingles with these latter young, ends up by talking like Yardley.

Je vous remercie, chère Madame.

\section{Hugh MacLennan}

And in case you're curious, no, there was no phonecall from either Messieurs Gérin-Lajoie or Lesage! The educational reform in Quebec was achieved, I'm sorry to say, without my precious help. But it was generous -- if somewhat unrealistic -- of MacLennan to suggest that it might be otberwise.

Some twelve days later, he felt bold enough to write me in French:

Hôtel de Savoie
avenue d'Alace-Lorraine
Grenoble, France
le 20 janvier 1964

Chère Madame,

J'ai donné un exemplaire de Deux Solitudes au professeur qui m'enseigne le français, une jeune femme très intelligente pour être l'épouse d'un avocat! (This to tease me, of course, as I happen to be in the same boat). Elle ne connaissait rien du Canada avant qu'elle n'ait fait notre connaissance.

A son avis, votre traduction est magnifique: le narratif fort et plein de poésie, le dialogue éclatant. Elle trouve le Capitaine absolument 


\section{Hugh MacLennan as I Knew Him}

formidable, et dans le livre même, un humour abondant, chose très rare dans la littérature française en ce moment actuel. Sa réponse, naturellement, m'a plu énormément, j'avais confiance en votre traduction, mais je parlais français tellement mal que je ne pouvais pas discuter d'une chose comme cela avec Monsieur $\mathrm{T}$. (the publisher who had complained about my relative dislike of the subjunctive tense!)

Je ne sais pas quand se trouvera le lancement; peut-être Mademoiselle Dumat attend-t-elle l'arrivée de notre nouvel ambassadeur. On m'avait dit que celui-ci devait être Lionel Chevrier, mais j'ai lu justement dans un journal français que ce dernier va à Londres.

En tout cas, il est bien possible que vous gagnerez pour Deux Solitudes un vrai succès en France. J'aime ce pays -- si singulier, aimable et subtil en toutes choses sauf la politique! Je serais très fier si la France, grâce à vous, acceptait mon livre.

\section{Bien amicalement, \\ Hugh MacLennan}

He would not leave it at that and a month later, began commenting in French on a lengthy review of Deux Solitudes signed in La Presse by Jean O'Neil. At first sceptical and expressing doubts about the actuality of the novel, O'Neil had finally rallied to it and had signed a most positive review. Here's MacLennan's letter about it

Hôtel de Savoie

le 22 février 1964

\section{Chère Madame,}

Je vous remercie vivement de vos très gentilles lettres et des coupures. J'ai trouvé particulièrement intéressant l'essai sur Deux Solitudes écrit par Jean O'Neil dans La Presse; j'en suis aussi fort encouragé, parce que celui-ci a abordé le livre avec scepticisme et même dans un esprit presque hostile. Comme il a dit luimême, les lecteurs d'aujourd'hui, selon les critiques, n'aiment pas un livre sérieux quand il compte plus de 600 pages. Mais il a raison, certes, quand il se plaint que dans ce livre, je n'ai pas présenté situations et caractères par "de brèves évocations". M. O'Neil n'est point le premier qui s'est irrité en lisant Deux Solitudes, mais il ne ressemble point aux critiques universitaires (je veux dire les critiques qui étaient aussi professeurs de littérature anglaise) parce qu'il a compris, lui, qu'il était nécessaire au temps de Deux Solitudes qu'un écrivain canadien se souvienne que le Canada n'est pas un pays connu. C'est Aristote qui a observé que le drame dépend du pouvoir du lecteur de faire les reconnaissances. Enfin, je suis très touché par M. O'Neil -- par son sens de la justice.

This typewriter lacks accents, and by now you will be out of patience with my maladresse in writing French. Nothing struck me as more characteristic of France, in her delightful but infuriating individuality, than to have a special clavier for her typewriters. I could not rent one without having to learn a new keyboard, so I bought a portable and paid to have about twelve keys changed. When this was done, all the accents had disappeared!

Only one thing did I wish to say to O'Neil. I agree totally that in general a writer should write at home. But $I$ have done this for 25 years, and the idea of being at home now, the telephone ringing twenty times a day -- no! I desperately needed a new perspective, and I hope I have gained one in France. I have come to love these people more than I have words to express, because it was like coming home from home. If only French Canadians would stop calling and thinking of the rest of us as Les Anglais! I am a Canadian -- as is almost everyone with a Scotch name -- because my ancestors were France's allies in the old wars and were expelled from Scotland as a result. In so many respects, I find the French of France and the English of England (not of today's England but of the older and better England) similar. But the French of the Dauphiné (they regard Lyon, 55 miles away, as foreign) are so like the Scotch in their character I don't know whether to laugh or cry. Nor, God 


\section{Hugh MacLennan as I Knew Him}

knows, has it ever been difficult for me to feel as a French Canadian. Three of my grandparents spoke Gaelic, and at the root of the intensity of feeling in Quebec is the fear of losing the mother's tongue. That fear need not be so strong. French Canada has secured that battle, and with it the meaning of Canada, for believe me, it is only in Canada -- never as a separate weak state, never as a part of the USA -- that the language can be saved.

I am glad to hear that an ambassador has at last been appointed, and from all that I have heard, Léger is an excellent man. I hope the lancement occurs while I am still in France, but we leave for home April 29, and wish to take about ten days in Italy first.

I presume that the book is in circulation in Canada. Once again, many, many thanks for what you have done for it. In its French version, this should be called "our" book.

\section{Sincerely, Hugh MacLennan}

A month later came an extraordinary letter in which his fascination with René Lévesque came out loud and clear, although MacLennan admits here that he views nationalism as being parochial and near-sighted.

Hôtel de Savoie

March 6, 1964

\section{Dear Madame,}

Two days ago I had lunch with Mr. Garneau,, cultural attaché of our Embassy in Paris, and I think the lancement here is fixed for April 7. The ambassador will not be here until the end of April, and they have decided to go ahead without him. I rather dread what is coming up. Apparently there will be a formal luncheon followed by a lengthy discussion of the book among a large number of Paris critics. Malraux may be there, but I'm not certain. A duke (I forget his title which is difficult) will be there; he is a descendant of Lévis and also an Académician (I think he meant le duc de Lévy-Mirepoix). I hate talking about my novels even in English. In French it will be very, very grim. Nor again have I any notion of its reception. I would guess it will be attacked because of its length and attention to detail, but I don't know. It was so long ago that I wrote that novel.

A clipping arrived from Le Nouvelliste which attacked the book as savagely as it was attacked in Le Devoir nineteen years ago. So I suppose it is now involved in Quebec politics, and I suppose that's a good thing, even though for me it was never intended to do anything but be a healer of wounds. I hope none of the hostility it is sure to create will rub off on you.

How things work out in Canada I do not know. I suppose Confederation wil hold up after a fashion, but the situation has become so neurotic that all I can see is the work of twenty years wiped out. Never have I had such a sense of déjà vu, such an absolute certainty that I was a better prophet, in the widest sense, than I knew I was or wished to be. Every nation that ever lived must go through these crises and I had truly hoped that Canada, and especially Quebec, was more psychologically mature than it is behaving at present. Those who refuse to remember the past are condemned to repeat it, and there is no release for humanity until men realize that nearly all of their political "causes" stem from personal wounds, generally suffered from infancy, and later projected onto others. Diefenbaker in a gross way is one example of that; Lévesque in a more sophisticated way is another. Lévesque is a socialist AND a nationalist. As the former is essentially international, and the latter parochial, each cancels the other out, though for a brief time, as in Europe 25 years ago, the combination of the two creates both change and emotional explosions. I'm terribly sorry about this, for Lévesque is such an enormously attractive character, and this I say without ever having met him.

Do forgive this letter. It may sound pessimistic, and politically it probably is. My own view about separatism is, I think, completely objective. If Quebec can thrive as a separate 


\section{Hugh MacLennan as I Knew Him}

state, then that is the way she should go. As I absolutely know she cannot, but would become fascist almost immediately if she did, and in a far worse position than she ever was since 1763, I hope the separatist thing will soon die out. Above all I wish people everywhere would accept the difficult truth that most problems can never be solved, they can merely be lived with.

Sincerely, Hugh MacLennan

About a fortnight later, on March 24, MacLennan writes again. After assuring me that he would have done so in French if it weren't for his infuriating accentless typewriter, he goes on in the following terms:

Canada's difficulty today is the inability of any but a few Canadians to think ahead to what the country could be like, must be like, if she is to survive: a dual country in which the solitudes protect and touch and greet each other with love and respect, thereby solving, in this area, the most difficult of all social-political problems of the future--how to preserve individuality within a vast economic common market, and so to avoid the fatal concentration which ruined the Roman Empire and dissolved, in the Dark Ages, into the very opposite--a vast mélange of tiny succession states having only two things in common-ignorance and poverty.

In this crisis there are two great temptations, on either side of the fence, so strong that each solitude, feeling it in itself, suspects, rightly, the existence of the same sentiment in the other. That is to follow the path of apparent least resistance. In practice this would mean that English-Canada, as hard pressed by the States as Quebec has been by English Canada, should give up and try to enter the American Union. It would probably be accepted after fifty more years, but no sooner, and in that time, of course, its character would be terribly damaged.

My personal feeling, confirmed by my stay in France, is that the French and English are curiously alike in their inner conviction that each should behave as the other does. As a Celt, I have felt myself in a sandwich between them ever since I can remember. However, what the Quebec French now call Les Anglais applies only to language, not to the old Anglo-Saxon point of view. The real Anglo-Saxons are in a very small minorité among the Canadian Anglophones.

Now back in Montreal, MacLennan wrote again at the beginning of the New Year to send me his best wishes. He had been reading Camus and commented on him:

1535 Summerhill Avenue Montreal, Quebec

January 6,1965

Dear Louise Gareau:

Thank you so very much for your New Year's note and the enclosed clippings about Deux Solitudes and les Editions HMH. The review in Evenement seemed quite good even though they did spell my name wrong.

Lately I have been reading Camus' non-fiction. How easily people today, especially the young, take for granted the victories such men as Camus won for them, and misunderstand the real meaning of novels like l'Etranger!

As for this country, I think it is in much better condition than it was a year ago, perhaps than it has been since 1949. I thought English-Canada would never wake up, but it has finally done so. I'm very sorry for Mike Pearson. He may not have been a good politician, but in all this misery he has at least upheld human dignity and has refused to betray men for political convenience.

All the best for 1965 .

Sincerely, Hugh MacLennan

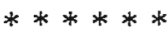

I believe that I have already exceeded my allotted 
time, so I ought to stop here and close my file, even though there was so much more I would have liked to tell you.

All the while I was writing this piece, the picture of MacLennan's summer home in North Hatley was on my table, a bleak, forlorn house separated from the lake by a country road. It stands alone, aloof and dignified, in a setting of huge, mature trees.

I was never there myself, but thanks to another strange coincidence it was my son Nicolas who happened to take these pictures, a client of his having bought the house with all its contents. Knowing of my association with the former owner, the new one had a thoughtful gesture and sent me a framed photograph of a young Hugh in his thirties, smiling hesitantly at the camera.

That Hugh MacLennan I never knew, but I firmly believe that he was the same one that I met some twenty years later: idealistic, intransigent, generous and yet intensely private, a man with a dream that he knew he would never see realized.

To me, Hugh MacLennan will always live on as the man who deeply believed with Rilke that

'love consists in this,

that two solitudes protect,

and touch, and greet each other". 